\title{
ANALISIS PEMANFAATAN TEKNOLOGI INFORMASI TERHADAP KUALITAS LAPORAN KEUANGAN PADA KELURAHAN SUKAJAYA KOTA PALEMBANG
}

\author{
Andini Utari Putri ${ }^{1}$ \\ Puspa Djuita ${ }^{2}$ \\ ${ }^{1}$ Fakultas Ekonomi, Universitas Indo Global Mandiri \\ Email: andini@uigm.ac.id \\ ${ }^{2}$ Ilmu Manajemen, STIE Aprin \\ Email: djuitapuspa@gmail.com
}

\begin{abstract}
ABSTRAK
Pemerintah perlu mengoptimalisasi pemanfaatan kemajuan teknologi informasi untuk membangun jaringan sistem informasi manajemen dan proses kerja yang memungkinkan pemerintahan bekerja secara terpadu dengan menyederhanakan akses antar unit kerja. Teknologi informasi selain sebagai teknologi komputer untuk pemrosesan dan penyimpanan informasi, juga berfungsi sebagai teknologi komunikasi untuk penyebaran informasi. Komputer sebagai salah satu komponen dari teknologi merupakan alat yang bisa melipatgandakan kemampuan yang dimiliki manusia dan komputer juga bisa mengerjakan sesuatu yang manusia mungkin tidak mampu melakukannya. Penelitian ini bertujuan untuk menganalisis pengaruh pemanfaatan teknologi informasi terhadap kualitas laporan keuangan pada Kantor Kelurahan Sukajaya Kota Palembang. Penelitian ini menggunakan observasi (pengamatan) dengan metode kualitatif desktiptif. Hasil penelitian menunjukkan bahwa Kantor Kelurahan Sukajaya sudah cukup memadai dalam hal teknologi infromasi walaupun alat-alat yang digunakan belum semuanya mencukupi untuk memberikan informasi yang diperlukan oleh rt ataupun rw sekitar. Karena semakin canggihnya yang teknologi yang digunakan semakin dapat memperkecil biaya yang digunakan.
\end{abstract}

Kata Kunci: Pemanfaatan Teknologi Informasi, Kualitas Laporan Keuangan

\section{PENDAHULUAN}

Dengan mengelola keuangan daerah dituntut supaya tertib, transparan, dan memiliki akuntabilitas yang tinggiguna mewujudkan pemerintahan yang bersih maka pemerintahan pada daerah diharuskan untuk menyusun Laporan Keuangan Pemerintah Daerah. Akuntabilitas dapat diartikan sebagai bentuk kewajiban mempertanggung jawabkan keberhasilan atau kegagalan pelaksanaan misi organisasi dalam mencapai tujuan dan sasaran yang telah ditetapkan sebelumnya, melalui suatu media pertanggungjawaban yang dilaksanakan secara periodik (Chodijah \& Hidayah, 2018).

Untuk menegakkan akuntabilitas finansial khususnya di pemerintah daerah, pemerintah daerah bertanggung jawab untuk mempublikasikan laporan keuangan kepada stakeholder. Pelaporan keuangan pemerintah daerah pada dasarnya merupakan asersi dari pihak manajemen pemerintah yang menginformasikan kepada pihak lain, yaitu para pemangku kepentingan (stakeholder), tentang kondisi keuangan pemerintah (Chodijah \& Hidayah, 2018)

Seiring perkembangan Akuntansi Sektor Publik di Indonesia, maka kebutuhan akan akuntabilitas sebagai wujud pertanggungjawaban kepada masyarakat atas kinerja pemerintah menjadi suatu tuntutan yang umum. Dalam PP No 8 tahun 2006 telah menjelaskan tentang pelaporan keuangan dan kinerja instansi pemerintah. Laporan keuangan dan kinerja instansi pemerintah daerah ini menggambarkan output atau hasil dari kegiatan yang hendak atau telah dicapai sehubungan dengan penggunaan anggaran dengan kuantitas dan kualitas terukur sehingga dapat menjelaskan kinerja dan tanggungjawab pengelolaan anggaran keuangan selama periode tertentu (Mene et al., 2018).

Teknologi informasi dengan kata lain ialah teknologi yang bisa dipakai untuk mengelolah data, dimana dapat diproses, mendapatkan, menyusun, menyimpan ataupun manipulasi data dengan bermacam macam cara supaya nantinya menghasilkan informasi yang akurat, baik kualitasnya dimana dengan kata 
lain informasi yang digunakan itu relevan, akurat dan tepat waktu untuk dipergunakan baik privasi, usaha atau bisnis ataupun pada bidang pemerintahan dan juga untuk informasi yang strategi untuk dilakukan pengambilan keputusan. Pemerintah perlu mengoptimalisasi pemanfaatan kemajuan teknologi informasi untuk membangun jaringan sistem informasi manajemen dan proses kerja yang memungkinkan pemerintahan bekerja secara terpadu dengan menyederhanakan akses antar unit kerja (Nurillah \& Muid, 2014).

Untuk mengetahui terminologi teknologi informasi, terlebih dahulu kita memahami pengertian teknologi dan informasi itu sendiri. Teknologi yaitu sistem umtuk melakukan sesuatu dalam memenuhi kebutuhan manusia dengan bantuan alat dan akal (Hardware dan Software) seolah-olah memperpanjang, memperkuat, atau membuat lebih ampuh anggota tubuh, panca indera dan otak manusia, sedangkan informasi adalah hasil pemrosesan, manipulasi, dan pengorganisasian atau penataan dari sekedar kelompok data yang mempunyai nilai pengetahuan bagi penggunanya (Mene et al., 2018). Pemanfaatan teknologi informasi tersebut mencakup adanya (a) pengolahan data, pengolahan informasi, sistem manajemen dan proses kerja secara elektronik dan (b) pemanfaatan kemajuan teknologi informasi agar pelayanan publik dapat diakses secara mudah dan murah oleh masyarakat di seluruh wilayah negeri ini (Chodijah \& Hidayah, 2018).

Laporan Keuangan menurut Peraturan Pemerintah Nomor 71 Tahun 2010 merupakan laporan yang terstruktur mengenai posisi keuangan dan transaksi- transaksi yang dilakukan oleh suatu entitas pelapor. Entitas pelaporan adalah unit pemerintahan yang terdiri dari satu atau lebih entitas akuntansi yang menurut ketentuan peraturan perundang-undangan wajib menyampaikan laporan pertanggungjawaban, berupa laporan keuangan bertujuan umum, yang terdiri dari: Pemerintah pusat; Pemerintah daerah; Masing-masing kementrian negara atau lembaga di lingkungan pemerintah pusat; dan Suatu organisasi di lingkungan pemerintah pusat/daerah atau organisasi lainnya (Damayanti et al., 2021). Pelaporan keuangan di pemerintah daerah maupun pusat mengacu dengan standar akuntansi pemerintah yang sesuai PP no 71 tahun 2010 mengenai Standar Akuntnsi Pemerintah (SAP) yang mana pengganti PP no 24 tahun 2005. SAP itu sendiri ialah prinsip - prinsip akuntansi yang diterapkan dalam menyusun dan menyajiikan laporan keuangan pemerintahan. Artinya SAP sebagai syarat yang punya kekuatan hukum untuk upaya menambah kualitas laporan keuangan pemerintah di Indonesia yang lebih berkualitas (Nadir \& Hasyim, 2017).

Disektor publik, laporan keuangan merupakan bentuk dari pertanggungjawaban pemerintah atas segala yang dilakukan dengan menggunakan anggaran yang berasal dari dana publik. Dana publik yang dimaksud adalah dana yang berasal dari masyarakat, misalnya pajak, retribusi dan pendapatan lainnya yang sah. Dana publik atau dana masyarakat ini memerlukan suatu pengelolaan keuangan daerah yang bertujuan agar pengelolaan keuangan rakyat oleh pemerintah dilakukan dengan transparan baik dari proses penyusunan hingga pertanggungjawabannya sehingga akan tercipta akuntabilitas didalam pengelolaannya (Karsana \& Suaryana, A, 2017).

Ada beberapa definisi laporan keuangan, salah satunya laporan keuangan sektor publik didefinisikan sebagai gambaran dampak keuangan dari transaksi dan peristiwa lain yang diklasifikasikan dalam beberapa kelompok besar menurut karakteristik ekonominya (Roswaty, 2017).

Permasalahan yang sering terjadi dalam pemanfaatan teknologi informasi ialah dari penerapannya teknologi informasi itu sendiri dimana berhubungan dengan perangkat keras, perangkat lunak yang diigunakan, pemutakhiran data dan kondisinya dari sumber daya manusia atau tenaga kerja yang berada lembaga itu sendiri serta terdapatnya keterbatasan dana. Dimana keterbatasan dana juga menjadi hal penting dikarenakan untuk memperbaharui teknologi yang ada pada kantor pemerintahan seperti kantor kelurahan masih terhambat seperti untuk memperbarui perangkat keras maupun perangkat lunak. Hal inilah yang menjadi faktor kendala yang mungkin terjadi pada kantor - kantor pemerintahan yang melayani masyarakat luas mengenai pemanfaatan teknologi informasi pada intansi pemerintahan yang belum efisien maupun belum optimal yang bisa saja memengaruhi pada kualitas laporan keuangan itu sendiri dengan menghambat pekerjaan yang akan diselesaikan sehingga kurangnya efektivitas da keefisienan dari pekerjaan yang dilakukan. Pada Kantor Kelurahan Sukajaya masih minim akan mengenai teknologi informasi sehingga mengenai informasi kepada masyarakat pun terhambat dengan minimnya informasi berbasis teknologi. 
Berdasarkan uraian latar belakang penelitian yang telah dijelaskan maka rumusan masalah dalam penelitian ini adalah bagaimanakah pengaruh pemanfaatan teknologi informasi terhadap kualitas laporan keuangan pada Kantor Kelurahan Sukajaya Kota Palembang?

Sesuai dengan permasalahan yang akan diteliti, maka tujuan penelitian adalah untuk mengetahui pengaruh pemanfaatan teknologi informasi terhadap kualitas laporan keuangan pada Kantor Kelurahan Sukajaya Kota Palembang.

\section{KAJIAN PUSTAKA \\ Teori Agency}

Teori keagenan (agency theory) merupakan agen dan prinsipal yang saling berkaitan. Prinsip yang utama dari teori tersebut ialah adanya kaitan kerja antara pihak yang memberikan wewenang (principal) dengan pihak yang menerima wewenang itu sendiri yaitu (agent). Principal merupakan pertanggungjawaban atas melakukannya pengambilan keputusan terhadap agent dimana dapat juga diartikan bahwa principal memberikan amanah kepada agent untuk melakukan jobdesk tertentu yang sesuai dengan kontrak kerja yang sudah disetujui bersama. Akuntabilitas publik merupakan kewajiban dari pihak yang memegang amanah yaitu agensi/pemerintah untuk memberikan tanggung jawab, menyajikan, melaporkan dan mengungkapkan semua activity dan kegiatan yang sudah menjadi tanggung jawab terhadap pihak yang memberikan amanah yaitu prinsipal / masyarakat yang mempunyai hak untuk meminta pertanggungjawaban tersebut (D Wulan A., Yudi., 2020).

Hubungan penelitian dengan teori keagenan yaitu mengenai prakter pada laporan keuangan yang ada pada organisasi pemerintahaan sektor publik dimana konsep yang didasari dari teori keagenan. Dalam hal ini laporan keuangan pada pemerintahaan yang berlaku sebagai agen yang memiliki kewajiban untuk memberikan atau menyajikan informasi yang memiliki manfaat untuk pengguna informasi keuangan pemerintah yang menjadi sebagai prinsipal dalam menilai akuntabilitas dan melakukan dengan membuat keputusan mengenai ekonomi, sosial politik dan yang lainnya. Disini juga dapat dikatakan mengenai hubungan pemerintah dengan pengguna informasi keuangan bahwa selaku pengguna juga harus paham dengan pengetahuan mengenai apa saja yang dapat mendukung mengenai pembuatan laporan keuangan itu sendiri.

\section{Teori Stewardship}

Teori stewardship adalah penggambaran kondisi manajer yang termotivasi dari target hasil utama kepentingan organisasi bukan termotivasi terhadap kepentingan pribadinya (Hanaffi, 2017). Teori ini didesain bagi para peneliti untuk menguji situasi dimana para eksekutif dalam perusahaan sebagai pelayan dapat termotivasi untuk bertindak dengan cara terbaik pada principalnya (Donaldson dan Davis, (1991) ; (Yaqin \& Jatmiko, 2018). Stewardship theory menjelaskan bahwa kepentingan bersama dijadikan dasar dari tindakan seorang manajer. Jika terdapat perbedaan kepentingan antara principal dan steward, maka steward akan berusaha bekerjasama karena bertindak sesuai dengan tindakan principal dan demi kepentingan bersama dapat menjadi pertimbangan yang rasional agar tercapainya tujuan bersama.

Teori stewardship dapat diterapkan pada organisasi sektor publik seperti organisasi pemerintahan dan non profit lainnya. (Fajar, 2012) ; (Hanaffi, 2017). Stewardship theory memandang bahwa manajemen organisasi sebagai steawards atau pelayanan. Pemerintah daerah sebagai stewards, penerima amanah menyajikan informasi yang bermanfaat bagi organisasi dan para pengguna informasi keuangan pemerintah. Dalam teori ini mengarah ke pendekatan governance yaitu menghasilkan informasi laporan keuangan yang berkualitas dengan mempertimbangkan faktor sosiologis dan psikologis.

Teori stewardship memperlihatkan tugas manajer melaksanakan fungsi-fungsi sesuai dengan prinsip manajemen dalam menggerakan roda organisasi sehingga mampu menjadi agen pelayanan kepada masyarakat. Untuk tercapainya pelayanan yang baik tentunya dari laporan keuangan yang berkualitas (Hanaffi, 2017). Untuk menghasilkan laporan keuangan yang berkualitas tentunya didukung oleh kompetensi sumber daya manusia yang mengerjakannya. 


\section{Laporan Keuangan}

Laporan Keuangan PSAK No. 1 tentang Penyajian Laporan Keuangan (revisi 2009) menyatakan laporan keuangan adalah suatu penyajian terstruktur dari posisi keuangan dan kinerja keuangan suatu entitas. Jadi laporan keuangan merupakan salah satu informasi yang sangat penting dalam menilai perkembangan perusahaan. Laporan keuangan dapat digunakan untuk menilai prestasi yang dicapai perusahaan pada saat lampau, sekarang dan rencana pada waktu yang akan datang. (Maith, 2013) keuangan adalah laporan yang menunjukkan kondisi keuangan perusahaan pada saat ini atau dalam suatu periode tertentu. Susilo (2009:10) ; Maith (2013) menyatakan bahwa laporan keuangan adalah hasil akhir dari proses akuntansi yang memuat informasi-informasi dan memberikan keterangan-keterangan mengenai data ekonomi perusahaan yang terdiri dari daftar-daftar yang menunjukan posisi keuangan dan hasil kegiatan perusahaan untuk satu periode yang meliputi neraca, laporan laba rugi dan laporan perubahan keuangan. Tujuan laporan keuangan yaitu untuk menyediakan informasi yang berkaitan dengan posisi keuangan, prestasi (hasil usaha) perusahaan serta perubahan posisi keuangan suatu perusahaan yang bermanfaat bagi pemakai dalam pengambilan keputusan ekonomi. PSAK No. 1 tentang Penyajian Laporan Keuangan (revisi 2009) menyatakan tujuan laporan keuangan adalah memberikan informasi mengenai posisi keuangan, kinerja keuangan, dan arus kas entitas yang bermanfaat bagi sebagian besar kalangan pengguna laporan dalam pembuatan keputusan ekonomi (Maith, 2013).

\section{Standar Akuntansi Pemerintahan}

Sejak tahun 2001, Indonesia memulai menjalankan prinsip desentralisasi dan otonomi daerah. Kebijakan ini telah mengubah penyelenggaraan pemerintah yang dulunya menjadi desentralisasi dimana adanya penyerahan kewenangan dan tanggung jawab pemerintah pusat kepada pemerintahan daerah. Disini pemerintahan daerah diberikan kewenangan dan juga tanggung jawab untuk melakukan pengurusan rumah tangganya sendiri mengenai administrasi pemerintahan amaupun mengenai pengelolaan keuangan yang diperlukan untuk kegiatan operasional dan layanan kepada masyarakat. Mengenai hal tersebut, pemerintahan daerah diharuskan untuk transparansi dan juga memiliki tanggung jawab atas semua pengelolaan keuangan daerah dalam menyajikan laporan keuangan daerah (Majid et al., 2016). Akuntansi pemerintahan sebagai sebuah kegiatan jasa dalam rangka menyediakan informasi kuantitatif terutama yang bersifat keuangan dari entitas pemerintah sebagai pengambilan keputusan ekonomi yang nalar dari pihakpihak yang berkepentingan atas berbagai alternatif arah suatu tindakan (Sudaryati \& Permana, 2020).

\section{Sistem Akuntansi Keuangan Daerah}

Akuntansi Keuangan daerah merupakan proses pengidentifikasian, pengukuran, pencatatan, dan pelaporan transaksi ekonomi (keuangan) dari entitas pemerintah daerah (kabupaten, kota, atau provinsi) yang dijadikan sebagai informasi dalam rangka pengambilan keputusan ekonomi yang diperlukan oleh pihak-pihak eksternal entitas entitas pemerintah daerah (kabupaten, kota, atau provinsi). Prosedur Sistem Akuntansi Keuangan Daerah (SAKD) menurut Kepmendagri No. 29 Tahun 2002, meliputi (Jauharusaniah et al., 2015):

1. Pencatatan

2. Penggolongan dan pengikhtisaran

3. Pelaporan

\section{Kualitas Laporan Keuangan}

Peraturan Pemerintah (PP No. 71 Tahun 2010) tentang Standar Akuntansi Pemerintahan (SAP) mengatakan bahwa laporan keuangan pemerintah ditujukan untuk memenuhi tujuan umum pelaporan keuangan, namun tidak untuk memenuhi kebutuhan khusus pemakainya. Kualitas laporan keuangan pemerintah sangat dipengaruhi oleh kepatuhan terhadap standar akuntansi dan didukung oleh sebuah sistem akuntansi yang handal. Karakteristik kualitatif laporan keuangan menurut (PP No. 71 Tahun 2010) adalah "Karakteristik kualitatif laporan keuangan adalah ukuran-ukuran normatif yang perlu diwujudkan dalam informasi akuntansi sehingga dapat memenuhi tujuannya". Keempat karakteristik berikut ini merupakan prasyarat normatif yang diperlukan agar laporan keuangan pemerintah dapat memenuhi kualitas yang dikehendaki; Relevan, Andal, Dapat Dibandingkan, dan Dapat Dipahami (Syahadatina, 2016). 


\section{METODOLOGI PENELITIAN}

Pada Kantor Kelurahan Sukajaya masih minim akan mengenai teknologi informasi sehingga mengenai informasi kepada masyarakat pun terhambat dengan minimnya informasi berbasis teknologi. Dalam penelitian ini dilakukan di Kantor Kelurahan Sukajaya yang bergerak dalam bidang pelayanan jasa pada pemerintahan dengan melayani masyarakat yang berada tinggal di Kelurahan Sukajaya Kota Palembang tersebut. Penelitian ini menggunakan metode kualitatif deskriptif analisis dengan melakukan observasi atau pengamatan secara langsung dengan mengamati mengenai pemanfaatan teknologi informasi yang dilakukan pada kantor Kelurahan Sukajaya tersebut dengan menganalisis pemanfaatan teknologi informasi yang memengaruhi terhadap kualitas laporan keuangan.

\section{PEMBAHASAN}

Hasil dalam penelitian ini memperlihatkan dimana instansi pemerintahan terkadang memandang tentang sistem informasi dan teknologi sebagai kebutuhan yang sesaat dalam pemanfaatanya dan masih minim dalam integritas yang mumpuni dalam melakukan penerapan pada sistem informasi dan teknologinya. Dimana hal tersebut perlu dilakukan evaluasi secara terus - menerus dengan sistem informasi kinerjanya setiap tahunnya. Pada Kantor Kelurahan Sukajaya sudah cukup baik. Dengan kata lain bahwa pemanfaatan teknologi informasi dapat dikatakan memengaruhi kualitas laporan keuangan. Oleh karena itu, semakin tingginya melakukan pemanfaatan teknologi informasi maka nilai informasi dari pelaporan keuangan yang dihasilkan pemerintah pun akan semakin bagus juga. Dalam hal ini dapat dikatakan bahwa pemanfaatan pada Kelurahan Sukajaya sudah cukup baik.

Dalam pemanfaatan teknologi informasi dapat memengaruhi nilai-nilai dari informasi pada laporan keuangan pemerintahan. Informasi-informasi yang dapat bisa sesuai waktu yang dapat diartikan sebagai bagian dari nilai-nilai informasi yang bisa digapai melalui peran komponen teknologi. Karena informasi sebagai produk yang berperan untuk sistem teknologi informasi yang bisa menyediakan informasi agar bermanfaat untuk yang berkepentingan dalam proses pengambilan keputusan dengan lebih efektif. Pemanfaatan teknologi informasi bisa memengaruhi keandalan dan ketepatan waktu laporan keuangan itu sendiri (Fernanda, 2014).

Kantor Kelurahan Sukajaya dengan melakukan pemanfaatan teknologi informasi dapat meminimalisir kesalahan-kesalahan yang mungkin bisa saja terjadi karena dalam menggunakan teknologi informasi pada suatu organisasi ataupun lembaga lainnya dari sisi pengendalian internal dengan benar dalam proses dengan frekuensi besar dalam transaksi data dan juga jika kantor Kelurahan Sukajaya melakukan pemanfaatan teknologi informasi akan dapat mempercepat proses informasi yang diinginkan agar dapat tingginya keefisienan dan efektivitas. Karena dengan adanya pemanfaatan teknologi informasi tersebut mengenai mengelola data-data, mengelola informasi yang ada di Kantor Kelurahan Sukajaya dan mengenai sistem manajemen dan proses pekerjaan secara elektronik serta mempermudah dan juga mempermurah dari proses pelayanan publik yang dapat diakses secara gampang serta meminimalisir biaya dari kantor - kantor dipemerintahan daerah walaupun hal ini juga berkaitan dengan sumber daya manusia yang juga harus mendukung.

Dengan melakukan pemanfaatan teknologi yang mendukung tentu dapat mempengaruhi proses penyaluran data juga dengan lebih cepat kepada masyakarat luas seperti pada saat adanya pemilu, retribusi pelayanan, peserta yang dianggap dapat dijadikan peserta pemuli serta yang lainnya dimana hal ini tentu memperkecil dari segi biaya, waktu maupun pembuangan kertas atau dari segi sumber daya yang bisa dialokasi ke hal yang lebih diperlukan. Walaupun disini dituntut untuk dapat transparansi dari pemerintahan daerah atau dari Kantor Kelurahan Sukajaya tersebut. (Pratama, 2015) dalam penelitian yang menurut peneliti bisa dijadikan sebagai contoh untuk Kantor Kelurahan Sukajya dimana mereka sudah menggunakan e-rt dan e-rw yang berinduk pada e-government (electronic government) yang diperuntukkan sebagai pelayanan publik. Dimana untuk $e-r t \& e-r w$ program tersebut bisa mengakses mengenai situs jaringan mengenai pertemanan sosial, lalu ada $e$-toko yang dapat mengakses kegiatan ekonomi di sekitar kelurahan mereka mengenai Usaha Kecil Mikro (UKM) dan e-government yang dapat menmambahkan wawasan masyarakat juga pengguna lainnya mengenai berita kota secara keseluruhan, proyek yang ada didaerah pengguna, kebutuhan informasi tentang kesehatan di kota tersebut dan juga lainnya. Disini peneliti berharap 
Kantor Kelurahan Sukajaya nantinya juga dapat melakukan perbaikan mengenai informasi berbasis teknologi kepada masyarakat disekitar mereka karena bisa menghemat biaya tentunya dan juga menghemat waktu serta memperluas informasi warga mereke sendiri.

Teknologi salah satu komponen yang dapat memengaruhi pada sektor publik yang begitu kompleks tugasnnya. Mengenai pemanfaatan teknologi informasi dalam aplikasi komputer akuntansi terhadap ruang lingkup pemerintahan pusat dan daerah yang merupakan hal penting untuk membantu para pegawai pada staf keuangan dalam melakukan pengolaan keuangan SKPD dan PPKD untuk menyusun laporan keuangan yang tinggi akan efektivitas dan ekonomis yang tentu berpacu pada standar akuntansi pemerintahan.

Pemanfaatan teknologi informasi berpengaruh pada kualitas laporan keuangan pemerintah daerah pada Kantor Kelurahan Sukajaya Kota Palembang. Pemerintah daerah melakukan pengelolaan transaksi keuangan berdasarkan APBD yang yang semakin banyak dikarenakan tingginya transaksi yang banyak ataupun permintaan yang banyak dalam pengurusan administrasi pada kantor - kantor pemerintahan dimana pemanfaatan teknologi informasi dengan menggunakan teknologi computer dan komunikasi dalam mengelola keuangan pemerintahan daerah yang akan menambah kualitas laporan keuangan baik dalam hal yang akurat maupun tepat waktu dalam menyajikan laporan keuangan.

\section{KESIMPULAN DAN SARAN}

Pemanfaatan teknologi informasi pada Kantor Kelurahan sudah cukup baik walaupun teknologi yang ada belum canggih ataupun memadai. Kantor Kelurahan Sukajaya dengan melakukan pemanfaatan teknologi informasi dapat meminimalisir kesalahan-kesalahan yang mungkin bisa saja terjadi karena dalam menggunakan teknologi informasi pada suatu organisasi ataupun lembaga lainnya dari sisi pengendalian internal dengan benar dalam proses dengan frekuensi besar dalam transaksi data dan juga jika kantor Kelurahan Sukajaya melakukan pemanfaatan teknologi informasi akan dapat mempercepat proses informasi yang diinginkan agar dapat tingginya keefisienan dan efektivitas. Serta dapat memperkecil biaya.

Berdasarkan hasil penelitian ini, peneliti memberikan saran praktis, bahwa kantor Kelurahan Sukajaya yang masih minim mengenai teknologi nantinya juga dapat melakukan perbaikan mengenai informasi berbasis teknologi kepada masyarakat disekitar mereka karena bisa menghemat biaya tentunya dan juga menghemat waktu serta memperluas informasi warga mereka sendiri seperti $e$-commerce yaitu $e$ $r t$ dan $e-r w$ untuk masing - masing masyarakat yang ada di sekitar wilayah Kelurahan Sukajaya tersebut.

Peneliti berharap dalam penelitian selanjutnya sebagai saran teoritis dapat menambahkan variable mengenai kompetensi sumber daya manusia, sistem akuntansi keuangan daerah, standar akuntansi pemerintahan dan pengendalian internal yang termasuk ke dalam faktor - faktor yang dapat memengaruhi kualitas laporan keuangan pada pemerintahan daerah.

\section{REFERENSI}

Chodijah, S., \& Hidayah, N. (2018). Pnegaruh Pemanfaatan Teknologi Informasi dan Sistem Pengendalian Internal Terhadap Kualitas Pelaporan Keuangan Pemerintah Daerah (Studi Kasus SKPD Provinsi DKI Jakarta). TEKUN: Jurnal Telaah Akuntansi Dan Bisnis, 9(1), 34-48. https://doi.org/10.22441/tekun.v8i1.2595

D Wulan A., Yudi., F. R. (2020). Pengaruh Latar Belakang Pendidikan, Pemanfaatan Teknologi Informasi dan Pemahaman Akuntansi Terhadap Kualitas Laporan Keuangan Pemerintah Daerah (Studi Pada OPD Di Pemerintah Kabupaten Muara Bungo). Jambi Accounting Review (JAR), 1(April), 1-19.

Damayanti, M., Marnisah, L., \& Zamzam, F. (2021). Pengaruh Kompetensi , Perilaku Organisasi Dan Komitmen Terhadap Kualitas Laporan Keuangan Direktorat Reserse Narkoba Polda Sumsel. Integritas Jurnal Manajemen Profesional (IJMPro), 2(1), 123-136. https://doi.org/https://doi.org/10.35908/ijmpro.

Fernanda, H. (2014). Pengaruh Pemanfaatan Teknologi Informasi Dan Pengawasan Keuangan Daerah Terhadap Nilai Informasi Pelaporan Keuangan Pemerintah Daerah (Studi Empiris .... Jurnal Akuntansi, 10(01), 13-20. http://ejournal.unp.ac.id/students/index.php/akt/article/view/867

Hanaffi, R. (2017). Faktor-faktor yang mempengaruhi kualitas laporan keuangan pemerintah daerah (studi empiris pada Satuan Kerja Perangkat Daerah Kabupaten Pati). Jurnal Institut Agama Islam Negeri Surakarta ..., 1(1), 121. 
Jauharusaniah, Manik, T., \& Fatahurrazak. (2015). Pengaruh Pengelolaan Keuangan Daerah, Sistem Akuntansi Keuangan Daerah Dan Partisipasi Penyusunan Anggaran Terhadap Kinerja Pemerintah Daerah Kota Tanjungpinang. Jurnal, 16, 1-16.

Karsana, W. I. \&, \& Suaryana, A, N. (2017). Pengaruh Efektivitas Penerapan Sap, Kompetensi Sdm, Dan Spi Pada Kualitas Laporan Keuangan Pemerintah Kabupaten Bangli. E-Jurnal Akuntansi Universitas Udayana, 21(1), 643-670.

Maith, H. A. (2013). Analisis Laporan Keuangan Dalam Mengukur Kinerja Keuangan Pada Pt. Hanjaya Mandala Sampoerna Tbk. Jurnal Riset Ekonomi, Manajemen, Bisnis Dan Akuntansi, 1(3), 619-628. https://doi.org/10.35794/emba.v1i3.2130

Majid, M., Jamaluddin, \& Anwar, P. H. (2016). Disclaimer Opinion: Pengungkapan Laporan Keuanganpemerintah Daerah. Journal of Chemical Information and Modeling, 53(9), 1689-1699.

Mene, R. E., Karamoy, H., \& Warongan, J. D. . (2018). Pengaruh Pemanfaatan Teknologi Informasi Dan Penerapan Sistem Pengendalian Intern Pemerintah Terhadap Kualitas Laporan Keuangan Pemerintah Daerah Kabupaten Halmahera Utara. Going Concern: Jurnal Riset Akuntansi, 13(04), 133-143. https://doi.org/10.32400/gc.13.03.20045.2018

Nadir, R., \& Hasyim, H. (2017). Pengaruh Pemanfaatan Teknologi Informasi, Kompetensi Sumber Daya Manusia, Terhadap Kualitas Laporan Keuangan Pemerintah Daerah Dengan Variabel Intervening Standar Akuntansi Pemerintahan Berbasis Akrual (Studi Empiris Di Pemda Kabupaten Barru). Akuntabel, 14(1), 57. https://doi.org/10.29264/jakt.v14i1.1007

Nurillah, A. S., \& Muid, D. (2014). Pengaruh Kompetensi Sumber Daya Manusia, Penerapan Sistem Akuntansi Keuangan Daerah (Sakd), Pemanfaatan Teknologi Informasi, Dan Sistem Pengendalian Intern Terhadap Kualitas Laporan Keuangan Pemerintah Daerah (Studi Empiris Pada Skpd Kota Depok). Journal Of Accounting, 3(2), 1-13.

Pratama, R. H. (2015). Pelananan Publik Berbasis Teknologi Informasi dan Komunikasi (TIK), Elektronik Rukun Tetangga/Rukun Warga (e-RT/RW) (Studi e-Government di Kelurahan Ketintang Kecamatan Gayungan Pemerintah Kota Surabaya). Jurnal Administrasi Publik (JAP), 3(12), 2128-2132.

Roswaty. (2017). Analisis Kemandirian Kinerja Pengelolaan Keuangan Daerah Provinsi Sumatera Selatan. Jurnal Ilmiah Ekonomi Global Masa Kini, 8(01), 21-27.

Sudaryati, E., \& Permana, T. D. (2020). Analisis Penerapan Standar Akuntansi Pemerintahan Berbasis Akrual Pada Dinas Kehutanan Provinsi Jawa Timur. Berkala Akuntansi Dan Keuangan Indonesia, 5(1), 1. https://doi.org/10.20473/baki.v5i1.16965

Syahadatina, R. (2016). Pengaruh Sumber Daya Manusia Bidang Keuangan Dan Sistem Pengendalian Internal Terhadap Kualitas Laporan Keuangan Pemerintah. Jurnal Akuntansi Dan Investasi, 1(1), 7792.

Yaqin, A., \& Jatmiko, B. (2018). Kontribusi Kompetensi Sumber Daya Manusia, Standar Akuntansi Pemerintah, Dan Sistem Pengendalian Internal Pemerintah Terhadap Kualitas Laporan Keuangan Pemerintah : Studi Kasus Pada Satuan Kerja Perangkat Daerah Kab. Biak Numfor. Reviu Akuntansi Dan Bisnis Indonesia, 2(1), 1-10. https://doi.org/10.18196/rab.020116 